\title{
Automation of Seed Priming Technology for Enhanced Seed Vigour of Blackgram Seeds
}

\author{
K. Malarkodi, T. Vedhapriya, R. Umarani, M. Bhaskaran
}

10.18805/LR-4662

\begin{abstract}
Background: Seed priming technique involves soaking of seeds in priming agent to a point where germination related metabolic activities occur in the seeds followed by drying of imbibed seeds to original moisture to prevent the radical protrusion and facilitate storage of primed seed. Draining of priming agent and drying of large quantity of primed seeds is a laborious and time consuming process. The current study was aimed to standardize automation of seed priming process by utilizing house-hold top loading washing machine.

Methods: The top loading washing machine referred to as Seed Priming Cabinet, contained a priming drum with provision for draining water. On completion of the soaking period, the 'SPIN' button was pressed by setting the duration of spin drying (1, 2, 3, 4 and 5 min.). Then the seeds were removed from the drum of priming cabinet and subjected to shade drying so as to reach the original moisture content and evaluated for seed quality parameters.

Result: The blackgram seed subjected to conventional hydropriming was compared with automatic seed priming for $1,2,3,4$ and 5 min. and observed that hydropriming and spin drying for $3 \mathrm{~min}$. was found to be optimum and the per cent increase in germination recorded over control was 18.0 per cent thus suggesting that automation of seed priming technology can be recommended for enhanced seed vigour and crop productivity of blackgram.
\end{abstract}

Key words: Automation of seed priming, Hydropriming, Seed quality, Spin drying.

\section{INTRODUCTION}

Seed is considered as one of the most important basic agricultural input for obtaining higher yield. To provide higher quality seeds, various seed quality enhancement techniques have been developed. In the last two decades, seed priming, an effective seed invigoration method, has become a popular seed treatment to increase the rate and uniformity of emergence as well as crop establishment and plant growth in most crops especially in advanced countries.

Seed priming technique involves soaking of seeds in water, osmoticants, halogens, sand matric, etc., to a point where germination related metabolic activities occur in the seeds followed by drying of imbibed seeds to original moisture to prevent the radical protrusion and facilitate storage of primed seed.

Draining of priming agent and drying of large quantity of primed seeds is a laborious and time consuming process. Top loading washing machine is household machine and that is easily available to farmers. The machine has a soaking drum with automatic draining facility and with spin drying option along with timer. The automatic draining of priming solution as well as spin drying options, which are two basic steps in seed priming process can be easily accomplished in this top loading washing machine. It was hypothesized that optimizing a house-hold top loading washing machine would be helpful to soak the seeds for the specific time, drain the water after the stipulated time and spin dry the seeds for a specific duration to complete the seed priming process. The spin drying will help the seeds to dry quickly to a particular level by removing the free employing centrifugal force. Since
Department of Seed Science and Technology, Tamil Nadu Agricultural University, Coimbatore-641 003, Tamil Nadu, India.

Corresponding Author: K. Malarkodi, Agricultural Research Station, Tamil Nadu Agricultural University, Coimbatore-641 003, Tamil Nadu, India. Email: jujumalar2000@gmail.com

How to cite this article: Malarkodi, K., Vedhapriya, T., Umarani, R. and Bhaskaran, M. (2021). Automation of Seed Priming Technology for Enhanced Seed Vigour of Blackgram Seeds. Legume Research. DOI: 10.18805/LR-4662.

Submitted: 13-05-2021 Accepted: 30-09-2021 Online: 09-11-2021

house hold washing machine are commonly available at affordable price, standardization of protocol will help to increase the adoptability of the seed priming technique by most farmers at farm level.

Against this background, efforts were taken to standardize the 'Top Loading Washing Machine' for automation of seed priming process. The basic study on adaptation involved standardization of spin drying duration of the seeds soaked in the drum subsequent to automatic draining.

\section{MATERIALS AND METHODS}

Fresh seeds of blackgram VBN 6 obtained from Department of Seed Science and Technology, Tamil Nadu formed of the study. The experiments and laboratory evaluations were carried out at the Department of Seed Science and Technology, Tamil Nadu Agricultural University, Coimbatore during 2018-2019. 
Automation of Seed Priming Technology for Enhanced Seed Vigour of Blackgram Seeds

\section{Seed priming cabinet}

The top loading washing machine will be hereafter referred to as Seed Priming Cabinet (Plate 1). it contained a priming drum with provision for draining water. One kilogram of seed were divided into two parts and seeds tied very loosely in cloth bags and placed in the drum filled with water. The drum can also agitated clock wise and anticlock wise to aerate the seeds during the soaking period of seed priming process. On completion of the soaking period, the 'SPIN' button was pressed by setting the duration of spin drying. Immediately, the solution in seed priming drum was automatically drained and the drum started to 'spin' centrifugally (@600 rpm) leading to expulsion of moisture from the seeds. The partially seeds were removed from the drum of priming cabinet and subjected to shade drying so as to reach the original moisture content. The major advantage of the machine is automatic draining of the water and 'hands free' partial drying of the seeds, which enables hassle free handling of seeds for further drying to original moisture content.

\section{Methods}

\section{Standardization of spin drying duration for mechanized seed priming technology}

One kilogram of blackgram seed was divided into two parts of $500 \mathrm{~g}$ each and packed in closely woven cloth bags. This is done for weight balancing of the machine. The priming machine was switched 'ON' and water level of 2 was selected. Water filled in the priming drum of the seed priming cabinet automatically. Once the water was filled, seeds packed in cloth bags were allowed to soak for $2 \mathrm{~h}$ in water (hydropriming) (Pegah et al., 2008).

After the soaking period, water was completely drained from the priming bin automatically by pressing the 'SPIN' button. Subsequently, the soaked seeds were subjected to 'Spin Drying' for different durations as furnished hereunder. The duration was maintained manually by switching the machine OFF.

\section{Treatment details}

$\mathrm{T}_{1}-1 \mathrm{~min}$.

$\mathrm{T}_{2}-2 \mathrm{~min}$

$\mathrm{T}_{3}-3 \mathrm{~min}$.

$\mathrm{T}_{4}-4 \mathrm{~min}$

$\mathrm{T}_{5}-5 \mathrm{~min}$

$\mathrm{T}_{6}$ - Conventional hydro priming and shade drying.

$\mathrm{T}_{7}$ - Control.

The primed seeds were shade dried at room temperature to bring them back to the original moisture content and evaluated for the following seed quality parameters.

\section{Moisture content (\%)}

Five grams of ground seed material of blackgram was placed in a moisture weighing bottle and kept in a hot air oven maintained at $130 \pm 1^{\circ} \mathrm{C}$ for $4 \mathrm{~h}$. After drying for specified period, the seeds were cooled in desiccator for $30 \mathrm{~min}$. and the weight of the seeds after drying was recorded.
The moisture content of the seed was calculated using the following formula and expressed in percentage (ISTA, 2007).

$$
\text { Moisture content }(\%)=\frac{M_{2}-M_{3}}{M_{2}-M_{1}} \times 100
$$

Where,

$M_{1}$ - Weight of bottle alone.

$M_{2}$ - Weight of bottle + seed sample before drying.

$\mathrm{M}_{3}$ - Weight of bottle + seed sample after drying.

\section{Fresh seed weight after spin dry (g)}

A known quantity of blackgram seed materials was weighed by using electronic balance and placed in priming bin before treatment started.

After each spin drying treatment the seed weight was calculated by using weighing balance to know the water removal of seed during spin drying and immediately after priming and expressed in gram.

\section{Speed of emergence}

Four replicates of twenty five seeds each were used to test the speed of germination of seeds from different treatments. The seeds showing radicle protrusion were counted daily from first day after sowing until final day of emergence. From the number of seeds germinated on each day, the speed of germination was calculated using the following formula and the result was expressed in number (Maguire, 1962).

$$
\text { Speed of germination }=\frac{X_{1}}{Y_{1}}+\frac{X_{2}-X_{1}}{Y_{2}}+\ldots \ldots . .+\frac{X_{n}-X_{n-1}}{Y_{n}}
$$

$X_{1}$ - Number of seeds germinated at first count.

$\mathrm{X}_{2}$ - Number of seeds germinated at second count.

$X_{n}-$ Number of seeds germinated on $n^{\text {th }}$ day.

$Y_{1}-$ Number of days from sowing to first count.

$Y_{2}-$ Number of days from sowing to second count.

$Y_{n}-$ Number of days from sowing to $n^{\text {th }}$ count.

\section{Germination (\%)}

Four replicates of 100 seeds each were germinated by using paper (Between paper) medium under the test conditions of $25 \pm 2^{\circ} \mathrm{C}$ temperature and $90 \pm 3 \% \mathrm{RH}$ maintained in a germination room illuminated with fluorescent light. After the test period of seven days, the number of normal seedlings in each replication was counted and expressed in percentage (ISTA, 2007).

\section{Root length (cm)}

At the time of germination count, ten normal seedlings were selected at random from each replication and used for measuring the root length of seedlings. Root length was measured from the point of attachment of seed to the tip of primary root. The mean values were calculated and expressed in centimetre.

\section{Shoot length (cm)}

The seedlings used for measuring root length were also used for measuring shoot length. The shoot length was measured 
from the point of attachment of seed to tip of the leaf and the mean values were expressed in centimetre.

\section{Dry matter production ( $\mathrm{mg}$ seedlings ${ }^{-10}$ )}

Ten normal seedlings used for measuring root and shoot length were dried in shade for $24 \mathrm{~h}$ and then, in a hot air oven maintained at $85^{\circ} \mathrm{C}$ for $48 \mathrm{~h}$ and allowed to cool in a desiccator for $30 \mathrm{~min}$. The dried seedlings were weighed in an electronic digital balance and the mean values were expressed in mg seedlings ${ }^{-10}$ (Gupta, 1993).

\section{Vigour index}

Vigour index value was computed using the following formula and the mean values were expressed in whole number (Abdul-Baki and Anderson, 1973).

$$
\begin{aligned}
& \text { Vigour index }=\text { Germination }(\%) \times \text { Seedling length }(\mathrm{cm}) \\
& \text { Electrical conductivity }\left(\mu \mathrm{Scm}^{-1}\right)
\end{aligned}
$$

Four replicates of twenty five seeds from each treatment were drawn, soaked in $25 \mathrm{ml}$ of distilled water for $6 \mathrm{~h}$ at room temperature. After soaking, the seed steep water was decanted to obtain the seed leachate. The electrical conductivity of the seed leachate was measured in a digital conductivity meter with an electrode having cell constant of one and expressed in $\mu \mathrm{Scm}^{-1}$ (Presley, 1958).

\section{Protein content (\%)}

A quantity of $100 \mathrm{mg}$ ground seed material was taken in a $50 \mathrm{ml}$ polyethylene screw cap bottle and to that $25 \mathrm{ml}$ of $1 \mathrm{~N}$ $\mathrm{NaOH}$ was added. The mixture was shaken for $30 \mathrm{~min}$. in a wrist action shaker to disperse the protein. Then, $10 \mathrm{ml}$ of the suspension was poured into a graduated test tube and used as a blank to compensate for the differences in the amount of natural pigments extracted and to the remaining suspension in the bottle, $0.25 \mathrm{ml}$ of 10 per cent copper sulphate solution was added and the bottle was reshaken for an additional duration of five minutes to develop the colour complex. The sample solution was then, poured into a separate test tube and left overnight along with its blank to allow the dispersed material to settle down. After centrifugation for $10 \mathrm{~min}$. The optical density (OD) of the clear supernatant solution was measured in an Optima UVVIS spectrophotometer (Model SP-3000) using red filter $(620 \mathrm{~nm})$ with corresponding blank. From the mean OD value, the protein content for each sample was calculated, using the following formula and expressed in percentage (Ali-Khan and Youngs, 1973).

$$
\text { Protein content }(\%)=3.78+(61.6 \times \text { OD value })
$$

\section{$\alpha$-Amylase activity (mg maltose min $^{-1}$ )}

Two replicates of $500 \mathrm{mg}$ of pregerminated seed samples were homogenised in $1.8 \mathrm{ml}$ of cold $0.02 \mathrm{M}$ sodium phosphate buffer ( $\mathrm{pH} \mathrm{6.0)}$ and centrifuged at 20,000 rpm for 20 minutes to extract enzymes. One $\mathrm{ml}$ of 0.067 per cent starch solution was added to $0.1 \mathrm{ml}$ of enzyme extract. The reaction was stopped after 10 minutes of incubation at $25^{\circ} \mathrm{C}$ by the addition of one $\mathrm{ml}$ of iodine $\mathrm{HCl}$ solution $(60 \mathrm{mg} \mathrm{KI}$ and $6 \mathrm{mg} \mathrm{l} 2$ in $100 \mathrm{ml}$ of $0.05 \mathrm{~N} \mathrm{HCl}$ ). Change in colour was measured at $620 \mathrm{~nm}$ and the OD value was recorded. The enzyme activity was calculated by using the following formula and expressed in mg maltose min $^{-1}$ (Paul et al., 1970).

$\alpha$ - Amylase activity $=$

$$
\frac{\text { OD value }}{\text { Volume of sample pipetted out }} \times \frac{1000}{500}
$$

\section{Statistical analysis}

The data obtained from various experiments were analysed for the ' $F$ ' test of significance adopting the procedure described by Panse and Sukhatme (1985). Wherever necessary, the per cent values were transformed to angular (Arc-sine) values before analysis. The critical difference (CD) was calculated at 5 per cent $(P=0.05)$ probability level and wherever ' $F$ ' value is non-significant it is denoted by 'NS'.

\section{RESULTS AND DISCUSSION}

\section{Moisture content (\%)}

The seeds hydroprimed and spin dried for $5 \mathrm{~min}$. recorded the lowest moisture content of $29.3 \%$ compared to seeds that were hydroprimed and spin dried for 4, 3, 2 and $1 \mathrm{~min}$. immediately after the treatment. Whereas, the seeds subjected to conventional priming treatment recorded the highest moisture content of $30.0 \%$.

After $24 \mathrm{~h}$ of shade drying, hydroprimed and spin dried seeds reached its original moisture content of $13.2 \%$. However, conventional hydropriming treatment recorded a higher moisture content of $14.2 \%$ (Table 1 ).

\section{Fresh seed weight after spin dry $(g)$}

The weight of hydroprimed and spin dried seeds showed significant differences due to spin drying duration. The seeds hydroprimed and spin dried for $5 \mathrm{~min}$. recorded the lowest fresh weight of $77 \mathrm{~g}$ followed by 4, 3, 2 and $1 \mathrm{~min}$. Whereas, the hydroprimed and shade dried (conventional hydropriming) seed recorded highest fresh weight by registering $81 \mathrm{~g}$. Due to priming the seed weight was increased to 7.4 per cent (Table 1).

\section{Speed of emergence}

Speed of emergence showed significant difference due to hydropriming and spin drying treatments. The seeds hydroprimed and spin dried for $3 \mathrm{~min}$. germinated fastly by registering the value of 11.54 which was followed by other treatments with the value range of 10.66 to 11.12 . The untreated seed germinated slowly and recorded the value of 10.92 (Table 2).

\section{Germination (\%)}

The germination per cent was statistically significant among the hydropriming and spin drying treatments. The seeds hydroprimed and spin dried for $3 \mathrm{~min}$. recorded significantly the highest germination (97\%) followed by the seeds hydroprimed and spin dried for 2 min. (96\%) which was on par to each other compared to control seed $(79 \%)$. The 
improvement in germination noticed with best treatment was 27.6 per cent higher than control seed and 14.8 per cent higher than primed seed (Table 2).

\section{Root length (cm)}

Significant differences were observed for root length due to treatments. Among the treatments seeds hydroprimed and spin dried for $3 \mathrm{~min}$. recorded significantly the highest mean root length of $17.0 \mathrm{~cm}$. It was closely followed by seeds hydroprimed and spin dried for $2 \mathrm{~min}$. $(16.9 \mathrm{~cm})$ both was on par with each other. The lowest value of $13.2 \mathrm{~cm}$ was recorded for untreated seeds. The best treatment of seeds hydroprimed and spin dried with 3 min. recorded 28.8 and 9 per cent increased root length over control and primed seeds respectively (Table 2 ).

\section{Shoot length $(\mathrm{cm})$}

The results revealed significant difference in shoot length among the treatments. It was more $(14.4 \mathrm{~cm})$ in seeds hydroprimed and spin dried for $3 \mathrm{~min}$. followed by seeds hydroprimed and spin dried for $2 \mathrm{~min}$. $(14.2 \mathrm{~cm})$ which was on par with each other. The control has lowest shoot length $(13.7 \mathrm{~cm})$ compared to other treatments (Table 2).

\section{Dry matter production ( $\mathrm{mg} \mathrm{seedlings}^{-10}$ )}

A significant increase in the dry matter production was registered in seeds hydroprimed and spin dried for $3 \mathrm{~min}$. (232 mg seedling ${ }^{-10}$ ) as against control and primed seed (187 and 199 mg seedling ${ }^{-10}$ ). The seeds hydroprimed and spin dried for $2 \mathrm{~min}$. and $1 \mathrm{~min}$. recorded the dry weight of 213 and $212 \mathrm{mg}$ seedlings $^{-10}$, respectively which was on par to each other (Table 2).

\section{Vigour index}

The computed vigour index values were significant among various treatments. Where, the seeds hydroprimed and spin dried for $3 \mathrm{~min}$. has recorded the highest vigour index value of 3048 remained significantly superior to all other treatments followed by the seeds hydroprimed and spin dried for 2 min. (2986) which was on par to each other. The improvement in seedling vigour in respect to above said best treatments were 43.4 and 40.5 per cent over control seeds, respectively (Table 2).

Table 1: Effect of hydropriming and spin drying on seed moisture content (\%) and fresh seed weight after spin dry (g) of blackgram.

\begin{tabular}{|c|c|c|c|c|c|c|}
\hline \multirow[t]{2}{*}{ Duration (D) } & \multicolumn{2}{|c|}{$\begin{array}{c}\text { Treatments } \\
(\mathrm{T})\end{array}$} & \multirow{2}{*}{$\begin{array}{c}\text { Moisture } \\
\text { content }(\%)\end{array}$} & \multicolumn{2}{|l|}{$\begin{array}{l}\text { Treatments } \\
\text { (T) }\end{array}$} & \multirow{2}{*}{$\begin{array}{c}\begin{array}{c}\text { Fresh seed } \\
\text { weight }(\mathrm{g})\end{array} \\
75\end{array}$} \\
\hline & & & & Dry weight (g) & & \\
\hline After hydro priming & & & 30.0 & Conventional primed seed weight & soaking (g) & 81 \\
\hline \multirow[t]{5}{*}{ Immediately spin dry } & & & 29.8 & Seed weight after spin drying $(\mathrm{g})$ & $1 \mathrm{~min}$ & 80 \\
\hline & & & 29.5 & & $2 \min$. & 79 \\
\hline & & & 29.5 & & $3 \mathrm{~min}$. & 79 \\
\hline & & & 29.3 & & $4 \mathrm{~min}$. & 78 \\
\hline & & & 29.3 & & $5 \mathrm{~min}$. & 77 \\
\hline \multirow[t]{5}{*}{$24 \mathrm{~h}$ after spin dry } & & & 13.8 & Mean & & 78.48 \\
\hline & & & 13.7 & SEd & & 1.36 \\
\hline & & & 13.7 & $C D(P=0.05)$ & & 2.91 \\
\hline & & & 13.6 & & & \\
\hline & & & 13.2 & & & \\
\hline Conventional Hydro priming & & & 14.2 & & & \\
\hline \multirow[t]{2}{*}{ Mean } & & & 20.4 & & & \\
\hline & $\mathbf{T}$ & D & $\mathbf{T} \times \mathbf{D}$ & & & \\
\hline SEd & 0.42 & 0.23 & 0.60 & & & \\
\hline$C D(P=0.05)$ & 0.87 & 0.46 & 1.23 & & & \\
\hline
\end{tabular}

Table 2: Effect of hydropriming and spin drying on seed quality parameters in blackgram cv.VBN 6.

\begin{tabular}{|c|c|c|c|c|c|c|}
\hline Treatments & $\begin{array}{c}\text { Speed of } \\
\text { emergence }\end{array}$ & $\begin{array}{c}\text { Germination } \\
(\%)\end{array}$ & $\begin{array}{c}\text { Root } \\
\text { length }(\mathrm{cm})\end{array}$ & $\begin{array}{c}\text { Shoot } \\
\text { length }(\mathrm{cm})\end{array}$ & $\begin{array}{l}\text { Dry matter production } \\
\left(\mathrm{mg} \mathrm{seedlings}^{-10}\right)\end{array}$ & $\begin{array}{l}\text { Vigour } \\
\text { index } \\
\end{array}$ \\
\hline Hydro priming and spin drying (1 min.) & 10.99 & $84(66.42)$ & 16.0 & 13.4 & 212 & 2465 \\
\hline Hydro priming and spin drying (2 min.) & 11.25 & $96(78.47)$ & 16.9 & 14.2 & 213 & 2986 \\
\hline Hydro priming and spin drying (3 min.) & 11.54 & $97(80.03)$ & 17.0 & 14.4 & 232 & 3048 \\
\hline Hydro priming and spin drying (4 min.) & 10.60 & $90(71.57)$ & 16.3 & 14.1 & 208 & 2736 \\
\hline Hydro priming and spin drying (5 min.) & 11.12 & $94(75.82)$ & 16.5 & 13.8 & 197 & 2846 \\
\hline Conventional hydro priming + shade drying & 11.17 & $88(69.73)$ & 15.6 & 13.7 & 199 & 2573 \\
\hline Control & 10.92 & $79(62.73)$ & 13.2 & 13.7 & 187 & 2126 \\
\hline Mean & 11.08 & $90(71.57)$ & 15.9 & 13.9 & 207 & 2683 \\
\hline SEd & 5.89 & 1.91 & 0.29 & 0.28 & 5.89 & 58.09 \\
\hline$C D(P=0.05)$ & 12.64 & 4.10 & 0.63 & 0.61 & 12.64 & 124.61 \\
\hline
\end{tabular}

(Figures in parentheses indicates arcsine values). 


\section{Electrical conductivity $\left(\mu \mathrm{Scm}^{-1}\right)$}

Lowest electrical conductivity was recorded in seeds hydroprimed and spin dried for $2 \mathrm{~min}$. $\left(147.6 \mu \mathrm{Scm}^{-1}\right)$ followed by $3 \mathrm{~min}$. $\left(156.7 \mu \mathrm{Scm}^{-1}\right)$. Whereas, control seeds showed high electrical conductivity $\left(165.3 \mu \mathrm{Scm}^{-1}\right)$ compared to hydropriming and spin drying treatments (Table 3 ).

\section{Protein content (\%)}

There was significant difference due to hydropriming and spin drying treatments. The seeds hydropriming and spin dryed for $3 \mathrm{~min}$. high protein content than others which recorded 7.1 per cent over nonprimed seed (Table 3).

\section{$\alpha$-amylase content ( $\mathrm{mg}$ maltose $\mathrm{min}^{-1}$ )}

Significant differences was recorded in amylase content which was initiated early at $1 \mathrm{~h}$ of soaking period. The results showed that hydroprimed and spin dried seeds for $3 \mathrm{~min}$.

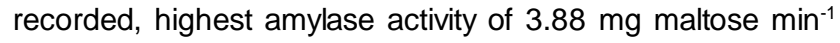
followed by $\left(2.98 \mathrm{mg}\right.$ maltose $\mathrm{min}^{-1}$ ) hydroprimed and spin dried for 2 min., hydropriming and shade drying $(2.90 \mathrm{mg}$ maltose $\mathrm{min}^{-1}$ ) and control (1.42 mg maltose $\mathrm{min}^{-1}$ ) seeds. The activity was increased with increase in soaking duration from $1 \mathrm{~h}\left(2.80 \mathrm{mg}\right.$ maltose $\left.\mathrm{min}^{-1}\right)$ to $3 \mathrm{~h}(3.71 \mathrm{mg}$ maltose $\mathrm{min}^{-1}$ ) irrespective of treatments (Table 3 ).

The blackgram seeds subjected to hydropriming and spin drying treatments for $1,2,3,4$ and 5 min. recorded lower moisture content of 13.8, 13.7, 13.7, 13.6, 13.2 per cent 24 hours after spin drying and also returned original moisture content very quickly compared to conventional hydropriming and shade drying, which is due to fast removal of higher percentage of surface and bound moisture through spinning from the soaked seeds. Besides rapid reduction in seed moisture content, the spin dried seeds also recorded maximum improvement in seed germination and seedling vigour compared to shade dried seeds, subsequent to hydropriming of seeds. The blackgram seeds hydroprimed and spin dried for $3 \mathrm{~min}$. increased the speed of emergence by 5.37 per cent, germination by 18 per cent, root length by 22.4 per cent and shoot length by 4.9 per cent (Plate 2) (Fig 1). Moreover, final emergence, shoot and root length, seedling fresh and dry weight were also improved. Improved starch metabolism was considered possible reason of seed invigoration.

The corresponding increase in computed vigour index subsequent to best spin drying duration was 30 per cent (Fig 1) over untreated seed. The study was supported by Rukui et al. (2002) and they obtained the highest germination percentage and lowest mean germination time from quick drying $\left(20 \% \mathrm{RH}, 20^{\circ} \mathrm{C}\right)$ for Guangxi 5 water melon seed. However, the hydroprimed seeds also showed higher seed quality parameters when compared to untreated seed, highlighting the superiority of priming over unprimed seed.

Table 3: Effect of hydropriming and spin drying on electrical conductivity $\left(\mu \mathrm{Scm}^{-1}\right)$, protein content (\%) and $\alpha$-amylase activity (mg maltose $\mathrm{min}^{-1}$ ) in blackgram.

\begin{tabular}{|c|c|c|c|c|c|c|}
\hline \multirow{2}{*}{ Parameters } & \multirow{2}{*}{$\begin{array}{l}\text { Electrical conductivity } \\
\qquad\left(\mu \mathrm{Scm}^{-1}\right)\end{array}$} & \multirow{2}{*}{$\begin{array}{c}\text { Protein } \\
\text { content (\%) }\end{array}$} & \multicolumn{3}{|c|}{ a-amylase (mg maltose $\min ^{-1}$ ) } & \multirow[t]{2}{*}{ Mean } \\
\hline & & & $1 \mathrm{~h}$ & $2 \mathrm{~h}$ & $3 \mathrm{~h}$ & \\
\hline Hydro priming and spin drying (2 min.) & 156.7 & 19.43 & 2.98 & 3.20 & 3.25 & 3.44 \\
\hline Hydro priming and spin drying (3 min.) & 147.6 & 19.47 & 3.88 & 3.41 & 4.00 & 3.46 \\
\hline Conventional Hydro priming + shade drying & 157.7 & 19.38 & 2.90 & 2.84 & 3.45 & 3.06 \\
\hline Control & 165.3 & 19.37 & 1.42 & 1.77 & 4.12 & 2.44 \\
\hline \multirow[t]{2}{*}{ Mean } & 155.6 & 19.41 & 2.80 & 2.81 & 3.71 & 3.10 \\
\hline & $\mathbf{T}$ & $\mathbf{T}$ & $\mathbf{T}$ & D & $\mathbf{T} \times \mathbf{D}$ & \\
\hline SEd & 0.14 & 0.08 & 0.02 & 0.02 & 0.04 & \\
\hline$C D(P=0.05)$ & 0.30 & 0.17 & 0.05 & 0.04 & 0.08 & \\
\hline
\end{tabular}

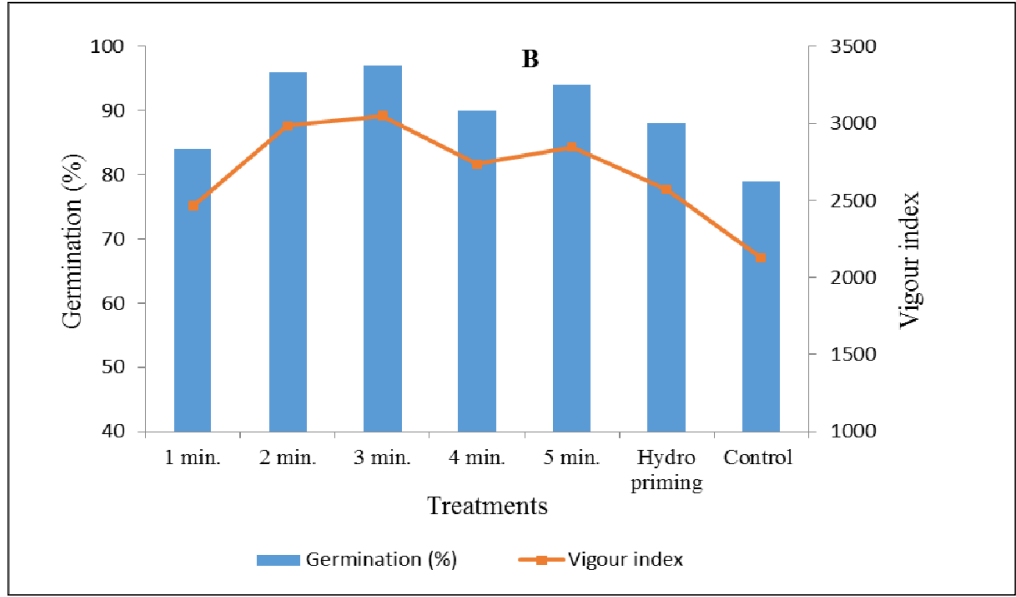

Fig 1: Effect of 'hydropriming and spin drying' on germination (\%) and vigour index in blackgram. 


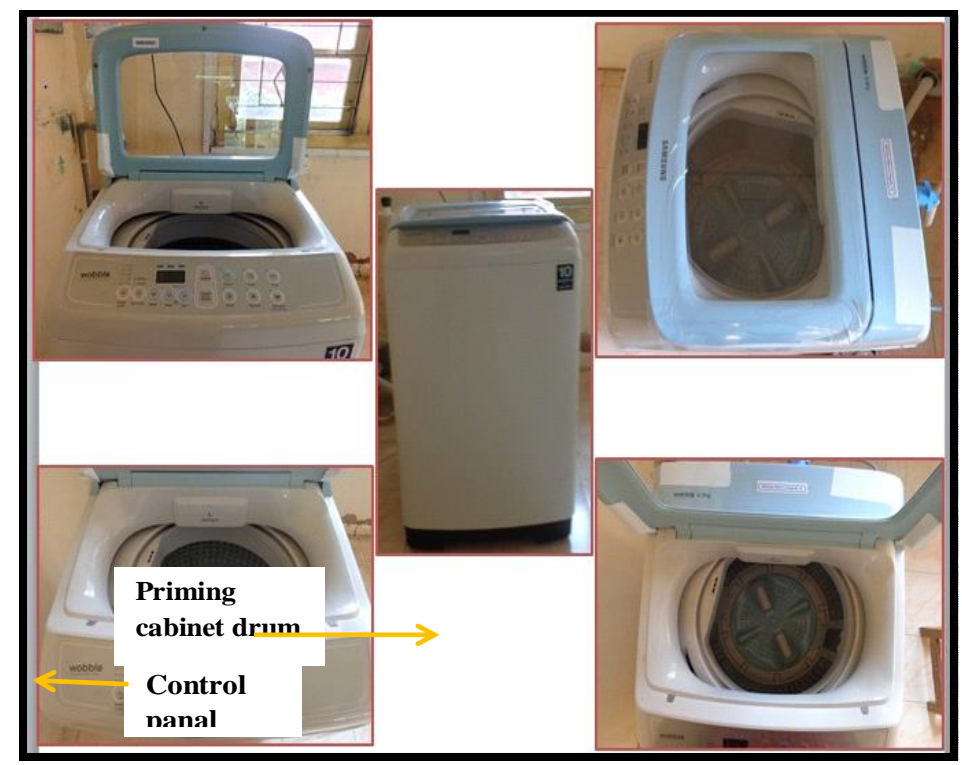

Plate 1: Seed priming cabinet.
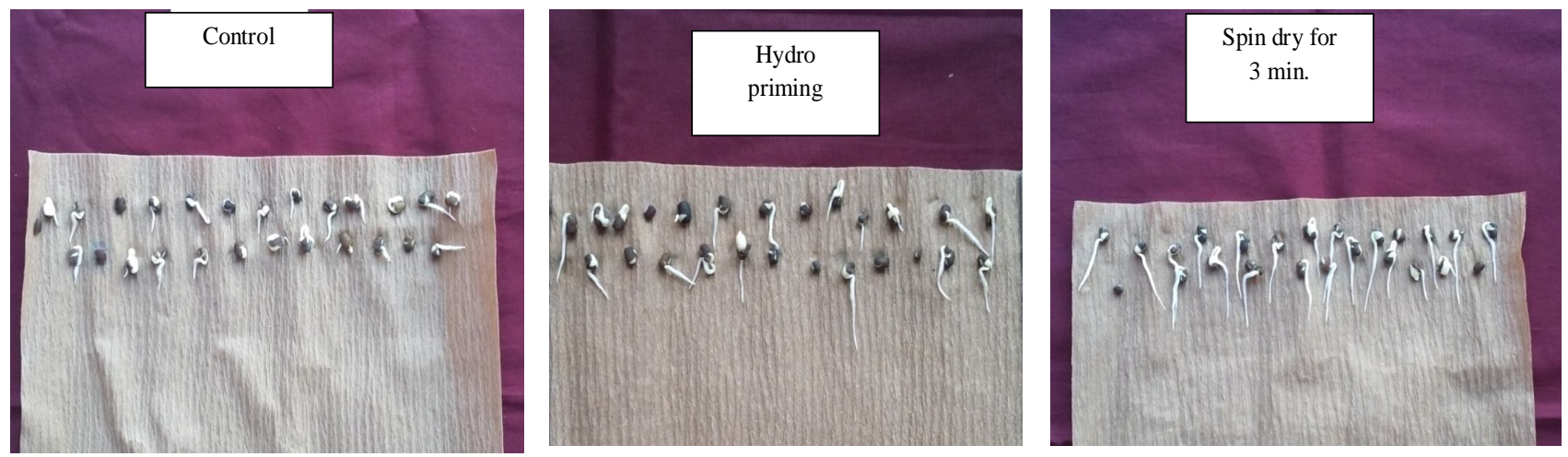

Plate 2: Effect of 'hydro priming and spin drying' on speed of germination in black gram.

This might be due to soaking of seeds which facilitates hydration of membranes and proteins and the initiation of various metabolic systems. The metabolic reactions get arrested when the imbibed seeds are dried back to original moisture content, but recommences quickly when the seeds soaked in water for the second time (Bewley and Black, 1982). Ashraf and Rauf (2001) reported that final germination percentage, fresh and dry weight of corn seed increased by seed priming significantly. The germination improvement with hydropriming might be due to hydrolysis of complex nutrients into simple sugars that are readily utilized in the synthesis of auxins and proteins. The auxins so produced help to soften cell walls to facilitate growth and the proteins readily utilized in the production of new tissues (Sabongari and Aliero, 2004). Copeland (1976) observed that most seeds imbibed in water and sown in moist environment, germinate faster than untreated seeds.

The measurement on release of metabolites through electrical conductivity test showed that it was lesser in hydroprimed and spin dried seeds for $3 \mathrm{~min} .\left(147.6 \mu \mathrm{Scm}^{-1}\right)$ compared to hydroprimed and shade dried and control seeds indicating that quantity of metabolites release and presence was less while recording before drying to original moisture content. Estimation of protein content immediately after treatment expressed the superiority of hydroprimed and spin dried seed. This might be due to higher level of protein synthesis due to early activation of amylase. The analysis of $\alpha$-amylase activity expressed that it was significantly higher when the seeds were subjected to hydropriming and spin drying. In blackgram spin drying recorded higher $\alpha$-amylase activity of $3.46 \mathrm{mg}$ maltose $\mathrm{min}^{-1}$ ( $3 \mathrm{~min}$.) while activity of 3.06 and $2.44 \mathrm{mg}$ maltose $\mathrm{min}^{-1}$ was recorded by shade drying and control, respectively.

The study reveals that although the duration of soaking was same, the method of drying of the seeds had immense effect on the level of invigoration of seeds. Apart from physical removal of moisture of water from the seeds, the spinning activity could have imparted mild stress to the seeds leading to differential protein synthesis with respect to quality as well as quantity of protein synthesized leading to significant improvement in spin dried seeds compared to conventionally shade dried seeds. 
Automation of Seed Priming Technology for Enhanced Seed Vigour of Blackgram Seeds

\section{CONCLUSION}

The hydroprimed seed subjected to spin drying for $3 \mathrm{~min}$. recorded significant improvement in the seed quality parameters over hydroprimed and shade dried seed. The presence of lesser metabolites, early activation of $\alpha$-amylase and stimulation of protein synthesis in spin dried seed compared to conventional shade dried seed and the cumulative effect on seed germination and seedling vigour purforth the possibility of utilizing commercial washing machines as seed priming cabinets by framers as well as seed companies.

\section{REFERENCES}

Abdul-Baki, A.A. and Anderson, J.D. (1973). Vigour determination of soybean seeds by multiple criteria. Crop Science. 13: 630-633.

Ali-Khan, S.T. and Youngs, C.G. (1973). Variation in protein content of field peas. Canadian Journal of Plant Science. 53: 3741.

Ashraf, M. and Rauf, H. (2001). Inducing salt tolerance in blackgram (Zea mays L.) through seed priming with chloride salts: Growth and ion transport at early growth stages. Acta Physiologiae Plantarum. 23(4): 407-414.

Bewley, J.D. and Black, M. (1982). Physiology and Biochemistry of Seeds in Relations to Germination. Vol. 2, Springer-Verlag, Berlin.

Copeland, L.O. (1976). Principles of Seed Science and Technology, Burges Pub. Co., U.S.A. Pp. 55-200.
Gupta, P.C. (1993). Seed Vigour Testing. Hand Book of Seed Testing. Quality Control and Research Development, New Delhi. P. 243.

ISTA, (2007). International rules for seed testing. Seed Science and Technology. 27: 27-32.

Maguire, J.D. (1962). Speed of germination - Aid in selection and evaluation of seedling emergence and vigour. Crop Science. 2: 176-177.

Panse, V.G. and Sukhatme, P.V. (1985). Statistical Methods for Agricultural Workers. ICAR Publication, New Delhi. P. 359.

Paul, A.K., Mukh Erji, S. and Sircar, S.M. (1970). Metabolic changes in rice seeds during storage. Indian Journal of Agricultural Science. 40(12): 1031-1036.

Pegah, M.D., Sharif Zadeh, F. and Janmohammadi, M. (2008). Influence of priming techniques on seed germination behaviour of blackgram inbred lines (Zea mays L.). ARPN Journal of Agriculture and Biological Science. 3(3): 2225.

Presley, J.T. (1958). Relationship of protoplast permeability of cotton seed viability and predisposition of seedling disease. Plant Disease Report. 42: 582.

Rukui, H., Sutevee, S. Thammasak,T.and Sunanta, J. (2002). Effect of hydropriming and redrying on the germination of triploid watermelon seeds. Kasetsart Journal. 36: 219-224.

Sabongari, S. and Aliero, B.L. (2004). Effects of soaking duration on germination and seedling growth of tomato (Lycopersicum esculentum Mill.). African Journal of Biotechnolology. 3: 47-51. 